\title{
RAD21 Gene
}

National Cancer Institute

\section{Source}

National Cancer Institute. RAD21 Gene. NCI Thesaurus. Code C93082.

This gene is involved in chromosomal cohesion, DNA repair and apoptosis. 